\title{
A Classic Presentation of Lyme Complete Heart Block
}

\section{Shagufta Ahsan ${ }^{1^{*}}$ and Norbert Scheffold ${ }^{2}$}

${ }^{1}$ Shore Medical Center, 5401 Hardings Highway, Mays Landing, New Jersey 08330, United States of America

2Department of Cardiology, Memmingen Medical Center, Affiliated Teaching Center at the LMU, Munich, Germany

*Corresponding author: Shagufta Ahsan, Shore Medical Center, 5401 Hardings Highway, Mays Landing, New Jersey 08330, United States of America, Tel: 9178085942; E-mail: shaguftaahsan@yahoo.com

Received date: January 25, 2016; Accepted date: February 22, 2016; Published date: February 26, 2016

Copyright: (C) 2016 Ahsan S, et al. This is an open-access article distributed under the terms of the Creative Commons Attribution License, which permits unrestricted use, distribution, and reproduction in any medium, provided the original author and source are credited.

\begin{abstract}
Lyme Borreliosis is a systemic disease caused by the spirochete Borrelia Burgdorferi and usually presents as early, localized and disseminated, as well as persistent or chronic disorder. If untreated with antibiotics, more than half the patients develop further complication. The least well developed complication is carditis. It has been estimated that $4-10 \%$ of untreated patients develop carditis complications.
\end{abstract}

Here we present a classic case of Lyme carditis, who had concomitant complete heart block and erythema chronicum migrans, as only $44 \%$ of patients with complete heart block were identified to have Erythema Migrans simultaneously.

\section{Case Report}

A 28 year old man was brought to the Emergency room because of sudden loss of consciousness in August, 2015. Patient denied any symptoms of systemic illness, no chest pain, shortness of breath, palpitation, nausea, vomiting, diarrhea, abdominal pain. No history of headache/seizure disorder noted. He had past medical history of alcohol abuse, but he stopped using alcohol several years back. He denied any illicit drug use history.

Patient is single, not currently sexually active; he lives in New Jersey and three weeks back patient visited his parents in Connecticut.

His general and physical examination were unremarkable except fever and rash. On examination, we found he had a fever of $101^{\circ} \mathrm{F}$. A targetoid erythematous skin rash (Highest diameter $15 \mathrm{~cm}$ ) with central clearing was found on the upper back, which seemed fading by the time patient presented in ER.

Except for a leukocytosis (White blood cell count was 12), the hematologic values and electrolytes were normal. EKG showed dissociative AV rhythm - third degree heart block, no ST changes. A CXR was normal. A CT scan of head was also normal.

The patient was admitted to the Coronary Care Unit and a transvenous temporary pacemaker was inserted the same day. For Early Disseminated Lyme Disease, as a presumptive cause of complete heart block, Ceftriaxone 2 gram intravenously daily was started and a transvenous pacemaker was temporally placed. The diagnosis of early Lyme disease was subsequently confirmed by positive ELISA and Western blot. Heart rate picked up, rhythm first converted to Mobitz type 2 second degree heart block and then to first degree heart block. On day 6 , when heart rhythm was first degree heart block, and the patient was symptom free, the transvenous pacemaker was turned off and removed. The patient was discharged home with a plan to administer Intravenous Ceftriaxone for a total duration of 2 to 3 weeks of IV Rocephin.

\section{Discussion}

Cardiac complications of Lyme disease generally occur in the early phase (Stage II) [1] and include conduction system disturbances, myopericarditis and congestive heart failure. Valvular involvement is not a characteristic of Lyme disease. Lyme carditis (stage II) presents after typical organotropic Borrelia burgdorferi disseminates hematogenously and preferentially to specific organ systems, which is weeks after the most common presentation of Lyme disease, skin rash, Erythema Chronicum Migrans (Figure 1) [1].

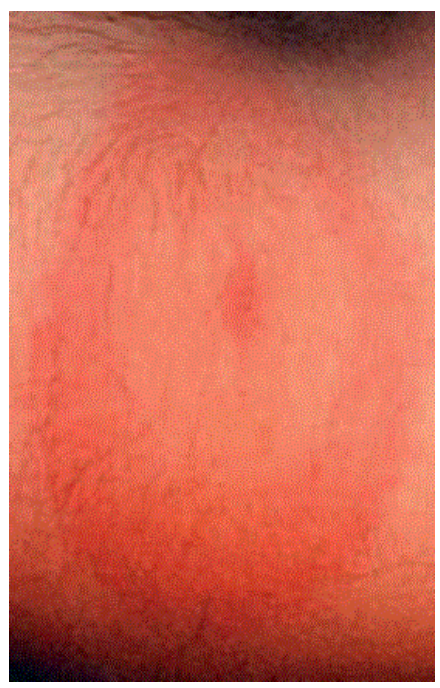

Figure 1: Erythema Chronicum Migrans on lower arm as an early manifestation of Lyme disease - Erythematous ring expanding peripherally. 
Page 2 of 2

Thus we see only $44 \%$ of patients with third degree heart block presents with ECM [2]. It is not impossible that the number of cases reported underestimates the true number of patients with third-degree heart block from Lyme disease.

Infectious or immune - mediated pathogenesis is suspected in many patients suffering from Lyme DCM. It is obvious that the presence of spirochetes in the myocardium is intrinsic to the pathophysiology of cardiac organ damage, by causing the inflammatory reaction induced by the spirochete infection, besides a direct destructive effect of the spirochetes.

Taking into account the guidelines of the European Federation of Neurological Societies on the diagnosis and management of Lyme neuroborreliosis, today Ceftriaxone (alternative: cefotaxime), administered over a period of two weeks, has become the standard antibiotic for the treatment of acute Lyme carditis [3]. Other recommendations include either oral or parenteral antibiotic therapy for 14 days (range, 14-21 days) (Table 1) [4].

\begin{tabular}{|c|c|c|}
\hline Indication & Treatment & $\begin{array}{l}\text { Duration, } \\
\text { days (range) }\end{array}$ \\
\hline Tick bite in the United States & $\begin{array}{l}\text { Doxycycline, } 200 \mathrm{mg} \text { in a single } \\
\text { dose; ( } 4 \mathrm{mg} / \mathrm{kg} \text { in children } \geq 8 \\
\text { years of age) and/or } \\
\text { observation }\end{array}$ & $\ldots$ \\
\hline Erythema migrans & Oral regimen & $14(14-21)$ \\
\hline \multicolumn{3}{|l|}{ Early neurologic disease } \\
\hline Meningitis or radiculopathy & Parenteral regimen & $14(10-28)$ \\
\hline Cranial nerve palsy & Oral regimen & $14(14-21)$ \\
\hline Cardiac disease & $\begin{array}{l}\text { Oral regimen or parenteral } \\
\text { regimen }\end{array}$ & $14(14-21)$ \\
\hline Borrelial lymphocytoma & Oral regimen & $14(14-21)$ \\
\hline \multicolumn{3}{|l|}{ Late disease } \\
\hline $\begin{array}{l}\text { Arthritis without neurologic } \\
\text { disease }\end{array}$ & Oral regimen & 28 \\
\hline \multirow[t]{2}{*}{$\begin{array}{l}\text { Recurrent arthritis after oral } \\
\text { regimen }\end{array}$} & Oral regimen & 28 \\
\hline & Or parenteral regimen & $14(14-28)$ \\
\hline Antibiotic-refractory arthritis & Symptomatic therapy & $\ldots$. \\
\hline $\begin{array}{l}\text { Central or peripheral nervous } \\
\text { system disease }\end{array}$ & Parenteral regimen & $14(14-28)$ \\
\hline $\begin{array}{l}\text { Acrodermatitis chronica } \\
\text { atrophicans }\end{array}$ & Oral regimen & $21(14-28)$ \\
\hline
\end{tabular}

\begin{tabular}{|l|l|l|}
\hline $\begin{array}{l}\text { Post-Lyme } \\
\text { syndrome }\end{array}$ & $\begin{array}{l}\text { Consider and evaluate other } \\
\text { potential causes of symptoms; if } \\
\text { none is found, then administer } \\
\text { symptomatic therapy }\end{array}$ \\
\hline $\begin{array}{l}\text { Note: Regardless of the clinical manifestation of Lyme disease, complete } \\
\text { response to treatment may be delayed beyond the treatment duration. Relapse } \\
\text { may occur with any of these regimens; patients with objective signs of relapse } \\
\text { may need a second course of treatment. }\end{array}$ \\
\hline
\end{tabular}

Table 1: Recommended therapy for patients with Lyme disease [4].

Although studies showed equal effectiveness of oral doxycycline and intravenous ceftriaxone in the treatment of acute disseminated Lyme disease, which included Lyme heart block patients, it has not been widely practiced and proven in various clinical settings yet [5].

In contrast, antibiotic treatment of a long - standing dilated cardiomyopathy based on the assumption of a past Borrelia infection cannot be recommended because of the inconsistency of the presently available data [1].

Management of Lyme disease is still evolving. Duration of antibiotics and the route of administration in different clinical settings of Lyme carditis need to be determined. Only very few studies have been conducted to determine the appropriateness and effectiveness of antibiotics in Acute Dilated Cardiaomyopathy and Conduction disorder. No conclusive studies or data on Chronic Dilated Cardiomyopathy cases are reported so far, nor has the need to use steroid in Cardiac Lyme disease been assessed adequately. Also actual Lyme carditis mortality and prevalences may be higher than assumed or documented [1].

\section{References}

1. Scheffold N, Herkommer B, Kandolf R, May AE (2015) Lyme Carditis Diagnosis, Treatment and Prognosis. Dtsch Arztebl Int 112: 202-8.

2. Forrester JD, Mead P (2014) Third -Degree Heart Block Associated with Lyme Carditis: Review of Published Cases. Clin Infect Dis 59: 996-1000.

3. Mygland A, Ljøstad U, Fingerle V, Rupprecht T, Schmutzhard E, et al. (2010) EFNS guidelines on the diagnosis and management of of European Lyme neuroborreliosis. Eur J Neurol 18: 8-16.

4. Wormser GP, Dattwyler RJ, Shapiro ED, Halperin JJ, Steere AC, et al. (2006) The Clinical Assessment, Treatment, and Prevention of Lyme Disease, Human Granulocytic Anaplasmosis, and Babesiosis : Clinical Practice Guidelines by the infectious diseases Society of America. Clin Infect Dis 43: 1089-134.

5. Dattwyler RJ, Luft BJ, Kunkel MJ, Finkel MF, Wormser GP, et al. (1997) Ceftriaxone compared with Doxycycline for the treatment of acute disseminated lyme disease. N Engl J Med 337: 289-94. 